\title{
Penerapan Algoritma Feature Selection Chi-Square (X2) Dalam Sistem Monitoring Tumbuh Kembang Balita
}

\author{
Khozainuz Zuhri*1 ${ }^{1}$, Fatimah Fahurian ${ }^{2}$, Yodhi Yuniarthe ${ }^{3}$ \\ ${ }^{1}$ Program Studi Informatika, Fakultas Komputer, Universitas Mitra Indonesia, Indonesia \\ ${ }^{2,3}$ Program Studi S-1 Sistem Informasi, Fakultas Komputer, Universitas Mitra Indonesia, \\ Indonesia \\ e-mail : ${ }^{1 *}$ zuhri@umitra.ac.id, ${ }^{2}$ fatimah_fahurian@umitra.ac.id, ${ }^{3}$ yodhi@umitra.ac.id
}

\begin{abstract}
Abstrak
Program keluarga sehat merupakan program prioritas kementerian kesehatan yang prinsipnya mengacu pada agenda ke-5 nawacita. Sejalan dengan program tersebut, pemerintah provinsi Lampung telah mencanangkan pembangunan pada sektor kesehatan diseluruh kota atau kabupaten dengan mengalokasikan 11,52\% anggaran khusus bidang kesehatan. Hal ini tidak terlepas dari kondisi pembangunan kesehatan khususnya kota Bandar Lampung dimana angka kematian bayi, angka kematian balita dan angka kematian ibu melahirkan yang semakin menurun. Kondisi pembangunan kesehatan tersebut, salah satunya dipengaruhi dari pos pelayanan kesehatan. Pos pelayanan kesehatan memiliki tenaga medis yang terbatas dan juga pencarian data pos kesehatan masih menggunakan model konvensional sehingga hasil yang didapatkan belum optimal. Berdasarkan hal tersebut, penulis mengusulkan untuk merancang sistem rekayasa perangkat lunak bidang kesehatan medis berupa sistem pemantauan tumbuh kembang balita dengan konsep algoritma feature selection Chi-Square atau X2. Hasil penelitian ini mampu memberikan sebuah model sistem monitoring berbasis web yang dapat diakses dimana saja dan kapan saja, mampu memberikan sebuah model sistem yang dapat memonitoring secara langsung kondisi pertumbuhan kesehatan balita dan mampu memberikan sebuah model sistem yang dapat dimanfaatkan oleh petugas kesehatan baik petugas medis maupun bidan untu memonitoring titik-titik pos kesehatan desa.
\end{abstract}

Kata Kunci - Sistem informasi, sistem monitoring, kesehatan, balita, chi square

\begin{abstract}
The healthy family program is a priority program of the ministry of health which in principle refers to the 5th nawacita program. In line with this program, the Lampung provincial government has launched development in the health sector in all cities or districts by allocating $11.52 \%$ of the special budget for the health sector. This is inseparable from the condition of health development, especially the city of Bandar Lampung, where the infant mortality rate, under-five mortality rate and maternal mortality rate are decreasing. One of the conditions of health development is the health service posts. Health service posts have limited medical personnel and health post data searches still use conventional models so that the results obtained are not optimal. Based on these descriptions, the authors propose to design a software engineering system in the field of medical health in the form of a toddler growth monitoring system with the concept of the Chi-Square or X2 feature selection algorithm. The results of this study are able to provide a web-based monitoring system model that can be accessed anywhere and anytime, able to provide a system model that can directly monitor the condition of toddler health growth and is able to provide a system model that can be used by health workers, both medical and midwives to monitor village health post points.
\end{abstract}

Keywords - Information systems, monitoring systems, health, toddlers, chi square

Received September $7^{\text {th }}, 2020$; Revised October $27^{\text {th }}, 2020$; Accepted October $31^{\text {th }}, 2020$ 


\section{PENDAhUluan}

Program keluarga sehat merupakan program prioritas kementerian kesehatan yang mengacu pada agenda ke-5 nawacita yaitu meningkatkan kualitas hidup manusia Indonesia. Program Indonesia sehat selanjutnya menjadi program utama pembangunan kesehatan yang kemudian direncanakan pencapaiannya melalui rencana strategis kementerian kesehatan tahun 2015-2019, yang ditetapkan melalui Keputusan Menteri Kesehatan R.I. Nomor HK.02.02/Menkes/52/2015 [1]. Sesuai dari program utama pembangunan kesehatan, pemerintah provinsi Lampung telah mencanangkan pembangunan sektor kesehatan diseluruh kota/kabupaten dengan mengalokasikan 11,52\% Anggaran Pendapatan Belanja daerah (APBD) khusus untuk bidang kesehatan [2][3]. Di kota Bandar Lampung, kondisi pembangunan kesehatan secara umum dapat dilihat dari status kesehatan dan gizi masyarakat, yaitu angka kematian bayi (AKB), angka kematian balita (AKABA), angka kematian ibu melahirkan (AKI), prevalensi gizi kurang dan umur angka harapan hidup. Tahun 2010 angka kematian bayi menurun dari 210 menjadi 169 per 100.000 kelahiran hidup (2014). Angka kematian balita menurun dari 25 (2012) menjadi 15 per 1.000 kelahiran hidup (2014) dan angka kematian ibu melahirkan menurun dari 228 (2007) menjadi 118 per 100.000 kelahiran hidup (2014). Sedangkan umur harapan hidup meningkat dari 885.363 jiwa tahun (2010) menjadi 960.695 jiwa tahun (2014). Prevalensi gizi kurang (underweight) pada anak balita, telah menurun sebesar $20 \%$ tahun 2014 [4].

Kondisi umum kesehatan yang telah diuraikan, salah satunya dipengaruhi dari pelayanan kesehatan. Pelayanan kesehatan memiliki parameter atau faktor penentu diantaranya, ketersediaan dan mutu fasilitas pelayanan kesehatan, obat dan perbekalan kesehatan, tenaga kesehatan, pembiayaan dan manajemen kesehatan. Terkait hal tersebut, peran pos pelayanan kesehatan sangat dibutuhkan oleh masyarakat dalam rangka meningkatkan pelayanan kesehatan. Pusat pelayanan pos kesehatan berpusat pada puskesmas di setiap daerah perkotaan dan pedesaaan. Pos pelayanan kesehatan memiliki tenaga medis yang terbatas untuk melakukan pelayanan masyarakat sehingga hasil yang didapatkan belum optimal. Selain hal tersebut, masalah yang terjadi pada dinas kesehatan Kedaton Bandar Lampung adalah pencarian data pos kesehatan masih menggunakan buku sehingga dalam pencarian masih memerlukan waktu dalam menemukan data setiap pos kesehatan atau pun puskesmas yang memantau kegiatan pos kesehatan tersebut.

Sesuai agenda ke-5 nawacita dalam mewujudkan dan mensukseskan program Indonesia sehat sekaligus mengatasi permasalahan tersebut khususnya masyarakat Kedaton Kota Bandar Lampung, peningkatan fasilitas bidang kesehatan medis (medical health) menjadi salah satu pertimbangan dari sekian upaya yang telah dilakukan. Salah satu upaya adalah dengan pemanfaatan inovasi teknologi yang menitikberatkan pada rekayasa perangkat lunak sistem pemantauan (monitoring system) tumbuh kembang balita dengan mobilitas yang lebih fleksibel sekaligus memiliki tampilan yang ramah dan mudah diakses. Fokus utama dalam penelitian ini adalah merancang sebuah sistem monitoring tumbuh kembang balita di bawah unit Posyandu yang ada di puskesmas Kedaton Kota Bandar Lampung dengan konsep algortima feature selection Chi-Square (X2). Sistem ini nantinya dapat digunakan oleh operator kesehatan, petugas kesehatan, bidan maupun petugas yang berwenang dalam menggunakan sistem ini. Sistem pemantauan ini nantinya dapat diakses dimana saja, dan juga dapat dijadikan tolak ukur pengambilan keputusan oleh petugas kesehatan dalam menentukan maupun mengantisipasi kondisi kesehatan masyarakat pada kawasan atau area desa untuk dapat dilakukan tindakan secara langsung dengan menyusun rencana, melaksanakan, mengumpulkan data dan mengevaluasi.

\section{METODE PENELITIAN}

Penelitian ini merupakan penelitian terapan, secara lebih luas, metode pengembangan sistem dalam penelitian ini menggunakan model proses sekuensial linier. Model sistem akan

IJEIS Vol. 10, No. 2, October 2020 : $199-210$ 
bekerja dalam kaitan dengan sisi perangkat keras (hardware), perangkat lunak (software), user interface, database dan file-file yang akan dibutuhkan [5].

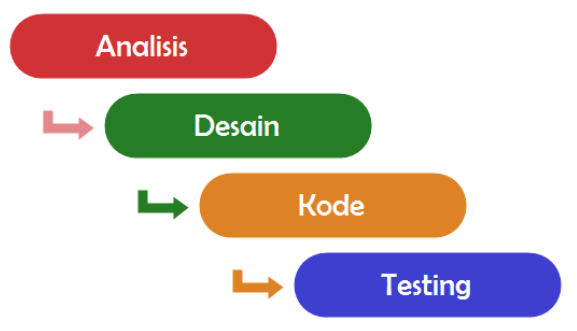

Gambar 1 Model Sekuensial Linier

\subsection{Analisis Sistem}

Analisis sistem dilakukan untuk memberikan arahan dan menentukan tahap proses pengerjaan selanjutnya. Analisa sistem dilakukan dengan wawancara operator, petugas, pengguna pos kesehatan, dan stakeholder yang terlibat dalam sistem pos kesehatan desa. Analisis sistem bertujuan untuk mengidentifikasikan dan mengevaluasi permasalahanpermasalahan, hambatan-hambatan yang terjadi, kebutuhan yang diharapkan dan kelayakan sistem. Penelitian ini menggunakan metode pengumpulan data dapat diperoleh secara langsung dari objek penelitian dan referensi-referensi yang telah diperoleh. Metode yang digunakan untuk memperoleh data adalah sebagai berikut :

\subsubsection{Studi literatur}

Secara garis besar penelitian serupa yang pernah dilakukan berisi pengembangan dari beberapa penelitian terdahulu yang sudah ada. Penelitian yang berhubungan dengan sistem pemantauan (monitoring system) tumbuh kembang kesehatan balita pernah dilakukan oleh Danie\&Nina (2017) dengan judul penelitian "Perancangan Sistem Informasi Posyandu Berbasis Web menggunakan Framework CodeIgniter". Sistem yang diusulkan adalah sistem informasi Posyandu, Metode perancangan sistem yang digunakan pada penelitian ini adalah metode prototyping. Aplikasi ini dibangun menggunakan Framework CodeIgniter dengan memanfaatkan teknologi navbar notifikasi sebagai pemberitahuan informasi posyandu terhadap pengguna aplikasi [6].

Penelitian yang menghasilkan paparan berupa temuan-temuan dan metodologi sistem monitoring tumbuh kembang kesehatan balita terkait kesehatan juga dibahas oleh Hilary et al (2017) yang berjudul "Development of a web based GIS for health facilities mapping, monitoring and reporting". Model pengembangan dengan memvisualisasikan informasi spasial terkait dengan kesehatan dengan menekannkan pada teknologi Geographic Information System (GIS). Penelitian ini bertujuan untuk menghasilkan GIS berbasis web yang dapat digunakan untuk mengumpulkan data dari fasilitas kesehatan dan memberikan data ke administrasi kesehatan masyarakat dalam mendukung pengambilan keputusan [7].

Penelitian oleh Erin\&Maheshwar (2016) yang berjudul "Using the Mobile Application ClickHealth to Provide Accessible Healthcare to the Homeless" mempresentasikan sebuah berbasis mobile yang membantu para tunawisma menemukan fasilitas perawatan kesehatan terdekat untuk membantu mengobati kebutuhan kesehatan. Sistem aplikasi yang dibangun memiliki fitur termasuk tampilan Google Maps, penanda (marker) yang menunjukkan rumah sakit dan toko obat terdekat, halaman info tentang rumah sakit, dan halaman menu favorit. Penelitian yang dilakukan oleh Erin\&Maheshwar bertujuan untuk membantu mengurangi jumlah tunawisma yang membutuhkan perawatan kesehatan dengan cara memandu pengguna ke fasilitas yang menerima pasien dan memungkinkan untuk dilakukan melalui telepon [8].

Penelitian terdahulu yang juga terkait dengan sistem monitoring tumbuh kembang kesehatan balita untuk pelayanan kesehatan pernah diteliti oleh Savitri\&Nurwasit (2017) yang berjudul "Pengembangan Aplikasi Mobile untuk Pelayanan Administrasi Posyandu dengan menggunakan Google Maps Api Geolocation Tagging". Penelitian yang dikembangkan 
memaparkan tentang pemanfaatan aplikasi Android untuk menunjang kegiatan Posyandu (Pos Pelayanan terpadu). Sistem yang dibangun berupa sebuah aplikasi yang dapat digunakan untuk menggantikan sistem administrasi Posyandu. Dengan aplikasi ini, kegiatan administrasi di Posyandu menjadi lebih efisien dan sekaligus mendorong ibu-ibu untuk memanfaatkan smartphone dengan aplikasi-aplikasi yang lebih produktif [9].

\subsubsection{Observasi}

Pengumpulan data dilakukan dengan melakukan observasi secara langsung ke pos kesehatan terpadu yang ada di Kedaton Bandar Lampung ke sekaligus melakukan pengumpulan data dengan mengadakan penelitian langsung terhadap permasalahan yang diambil. Observasi ini dilakukan untuk guna mendapatkan informasi berupa data-data mengenai proses alur dari imunisai pada pos kos kesehatan terpadu yang telah berjalan.

\subsubsection{Analisis Kebutuhan Perangkat Keras dan perangkat lunak}

Perangkat keras utama dalam sistem ini berupa satu unit komputer yang hanya dalam proses pemrograman dan koding menggunakan pemrograman asynchronous javascript and XML (AJAX), hypertext preprocessor (PHP), javascript object notation (JSON), dan MySQL dengan PHPMyAdmin. Selain itu, ditambahkan beberapa library untuk mendukung proses program.

\subsubsection{Algoritma Feature selection Chi-Square (X2)}

Chi-Square atau X2 adalah salah satu metode dari feature selection atau pemilihan fitur yang termasuk dalam model pendekatan metode filter [10]. Pada umumnya metode feature selection ini, digunakan pada tahap pre-processing. Metode Chi-squared adalah suatu pengujian statistik untuk mengukur kesamaan antara hasil model yang diharapkan dengan yang sebenarnya [11]. Chi-square digunakan untuk menentukan apakah ada perbedaan penting antara frekuensi yang dapat diprediksi dan frekuensi yang diamati dalam satu atau lebih jenis data [12]. Untuk pemilihan fitur atau feature selection, evaluasi fitur kai-kuadrat digunakan untuk menilai nilai fitur dengan menghitung skor chi-kuadrat kelas, untuk mendapatkan daftar peringkat semua fitur [13]. Metode ini telah digunakan dalam beberapa aplikasi, seperti klasifikasi tumor [14], deteksi intrusi jaringan [15], klasifikasi teks [16], diagnosis penyakit [17] dan lain-lain. Skor chi-kuadrat dari suatu fitur dihitung menggunakan rumus yang ditunjukkan pada persamaan (1).

$$
\chi^{2}=\sum_{i=1}^{k} \frac{\left(o_{i}-e_{i}\right)^{2}}{e_{i}}
$$

Dimana, Oi : Frekuensi Observasi, Ei : Frekuensi Harapan, m : Banyaknya kategori/kelas(x) $\alpha$, $\alpha$ : Taraf (Standard 5\%) dan v : Derajad Kebebasan (m-k-1). Uji statistika ini merupakan uji non parametrik yaitu uji dengan jumlah populasi yang tidak diketahui.Pengujian ini umumnya dilakukan dengan menggunakan dua variable dengan tujuan untuk melihat adakah perbedaan yang nyata antara frekuensi observasi (Oi) dengan frekuensi yang diharapkan (Ei). Jika nilai yang ditandatangani lebih kecil dari titik krisis yaitu 0,05, maka fitur tersebut memiliki relevansi yang kuat dalam data, dengan kata lain fitur tersebut merupakan fitur yang penting. Gambar 2.5 menunjukkan grafik distribusi Chi Square untuk df $=1$. Nilai df diperoleh dengan cara mengurangi jumlah kelas target (dalam hal ini kelas target = " lulus " atau " tidak lulus ") dengan $1(\mathrm{df}=\mathrm{n}-1)$. Gambar 2. Grafik distribusi Chi Square untuk df $=1$ [18].

IJEIS Vol. 10, No. 2, October 2020 : $199-210$ 


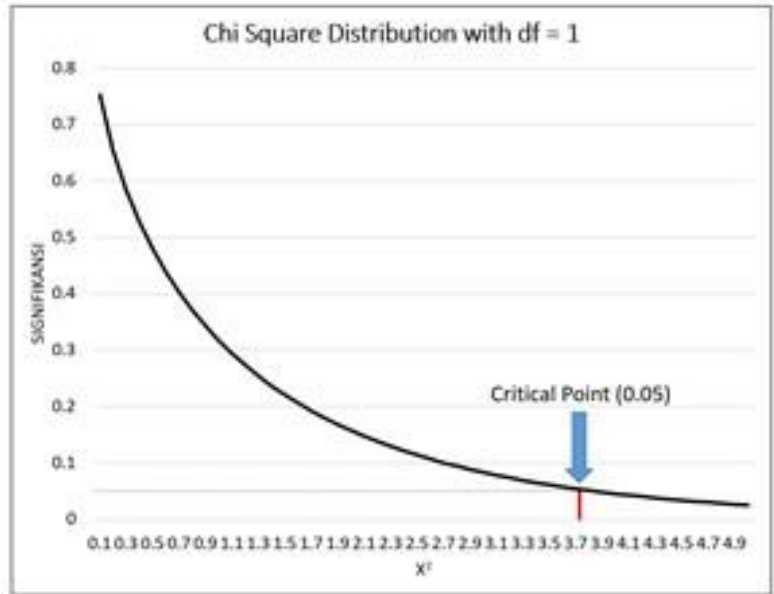

Gambar 2 Distribusi Chi Square untuk df $=1$.

\subsection{Rancangan Database}

Pembuatan Sistem membutuhkan rancangan basis data yang sesuai dengan kebutuhan sistem informasi monitoring tumbuh kembang balita, Rancangan struktur tabel merupakan garis besar dari seluruh proses komputerisasi pengolahan data. Perancangan database aplikasi sistem informasi secara detail dari masing-masing struktur tabel-tabel sistem dari segi pendefinisian kelas-kelas yang akan dibuat untuk membangun sistem informasi monitoring tumbuh kembang balita dapat digambarkan pada Gambar 3.

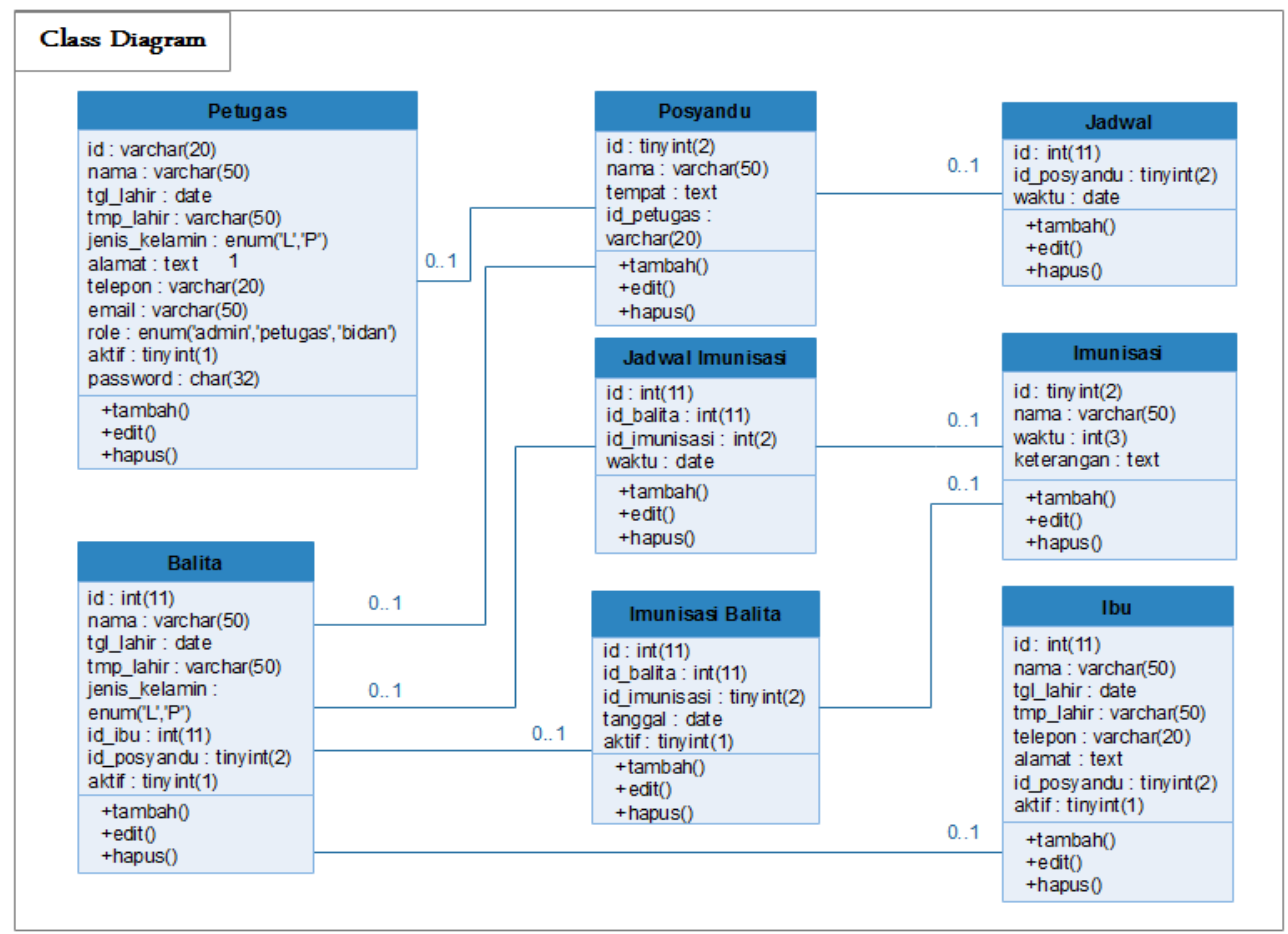

Gambar 3 Struktur sistem daam kelas diagram

Perancangan ini mencakup penentuan dalam kunci utama yang menghubungkan tabel yang satu dengan tabel yang lainnya, yaitu :

1. Tabel petugas yang digunakan untuk akses sesuai dengan identitas penguna, sebagai contoh akses pengguna admin, petugas maupun bidan digunakan untuk masuk ke 
halaman utama (home page) dengan menu atau fitur yang berfungsi untuk mengelola sistem sesuai dengan identitas pengguna

2. Tabel pos kesehatan yang digunakan untuk menentukan pos-pos atau titik-titik lokasi yang akan dipantau.

3. Tabel jadwal yang digunakan untuk menentukan waktu dan lokasi pelayanan calon pengguna kesehatan

4. Tabel jadwal imunisasi yang digunakan untuk menentukan jadwal imunisai setiap pelayanan kesehatan yang ada di pos pelayanan kesehatan.

5. Tabel imunisasi balita yang digunakan dalam pelaksanaan kesehatan imu.nisasi balita yang sesuai dengan waktu yang telah ditentukan.

6. Tabel imunisasi yang digunakan untuk menentukan nama pos imunisasi sesuai dengan waktu dan jenis layanan kesehatan imunisasi

7. Tabel ibu yang digunakan untuk memanajemen identitas pengguna atau calon yang ingin melakukan pengobatan atau pemeriksaan kesehatan.

8. Tabel balita yang digunakan untuk memanajemen identitas pengguna atau calon yang ingin melakukan pengobatan atau pemeriksaan kesehatan.

\subsection{Rancangan tampilan sistem monitoring}

Antarmuka pengguna merupakan output atau keluaran sistem yang berupa tampilan grafis dan berhubungan langsung oleh pengguna (user). Perancangan sistem menggunakan antarmuka berbasis web sebagai output tampilan grafis yang digunakan oleh pengguna. Berdasarkan analisa data, layout rancangan struktur halaman utama monitoring pada sistem informasi monitoring pos kesehatan berbasis web ditunjukkan pada Gambar 4.

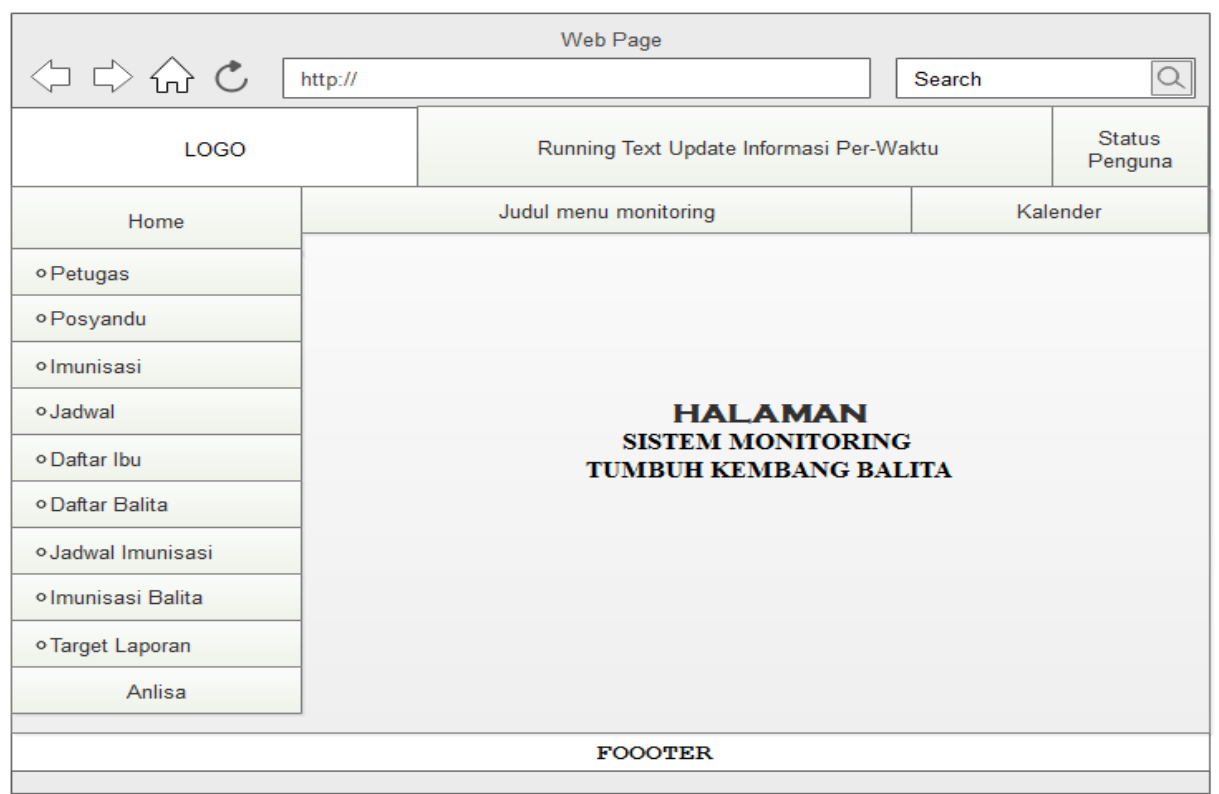

Gambar 4 Rancangan Layout Halaman Utama

\subsection{Pengujian dan implementasi sistem}

Pengujian sistem ini merupakan salah satu bagian yang penting dalam pembangunan perangkat lunak. Pengujian sistem akan menguji seberapa baik sistem ini dalam memenuhi kebutuhan, kegunaan dan kinerja [5]. Pengujian dengan metode blackbox memungkinkan pengembang perangkat lunak untuk membuat himpunan kondisi input yang akan menentukan seluruh syarat-syarat fungsional suatu program. Pengujian ini dilakukan dengan mencoba semua kemungkinan yang terjadi dan dilakukan lebih dari sekali, jika dalam pengujian tersebut ditemukan sebuah kesalahan maka akan dilakukan pengecekan dan perbaikan. 


\section{HASIL DAN PEMBAHASAN}

Penerapan sistem informasi monitoring tumbuh kembang balita di bawah unit Posyandu yang ada di puskesmas dengan konsep algortima feature selection Chi-Square (X2) dilakukan dengan bahasa pemrograman HyperText PreProcessor (PHP) dengan kombinasi basis data dengan MySQL versi 1.4. Penggunaan bahasa pemrograman PHP dapat dijalankan pada berbagai platform sistem operasi dan perangkat keras.

\subsection{Implementasi basis data}

Database pada sistem ini menggunakan MYSQL, untuk pembuatan database menggunakan PHPMyAdmin dan nama database yang dibuat adalah puskesmaskedatondb.sq1 berikut ini adalah tampilan dari struktur tabel dalam database pusekemaskedaton. sql di paparkan dalam Gambar 5.

$\begin{aligned} & \text { Table } \Delta \\ & \text { balita }\end{aligned}$ Action
ibu

Gambar 5 Implementasi strukur tabel database

\subsection{Implementasi antarmuka pengguna (user interface)}

\subsubsection{Halaman utama monitoring}

Halaman ini merupakan halaman dashboard yang digunakan oleh operator admin, petugas kesehatan dan bidang dalam memonitoring tumbuh kembang balita setelah melakukan login. Halaman admin merupakan halaman yang memiliki paling banyak fitur menu-menu yang digunakan untuk mengelola keseluruhan sistem montiroing tumbuh kembang balita.

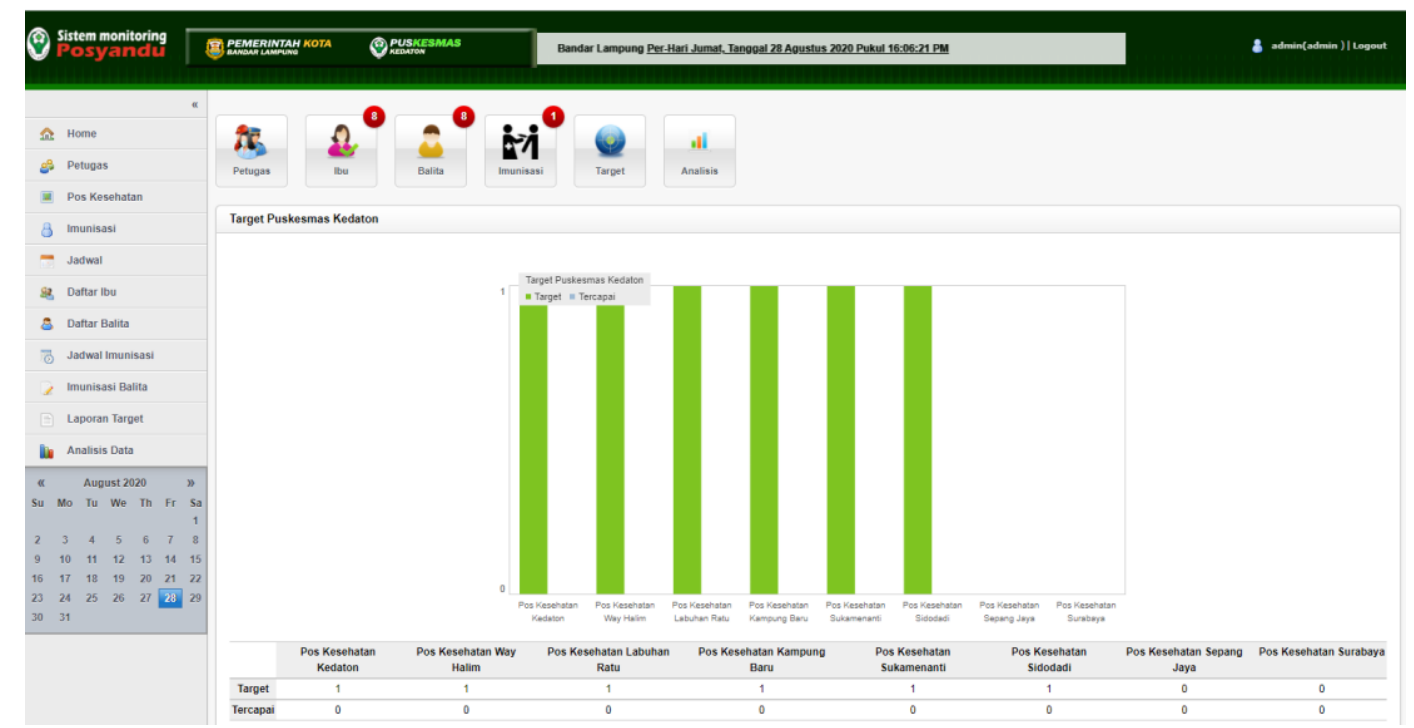

Gambar 6 Implementasi halaman utama Admin 


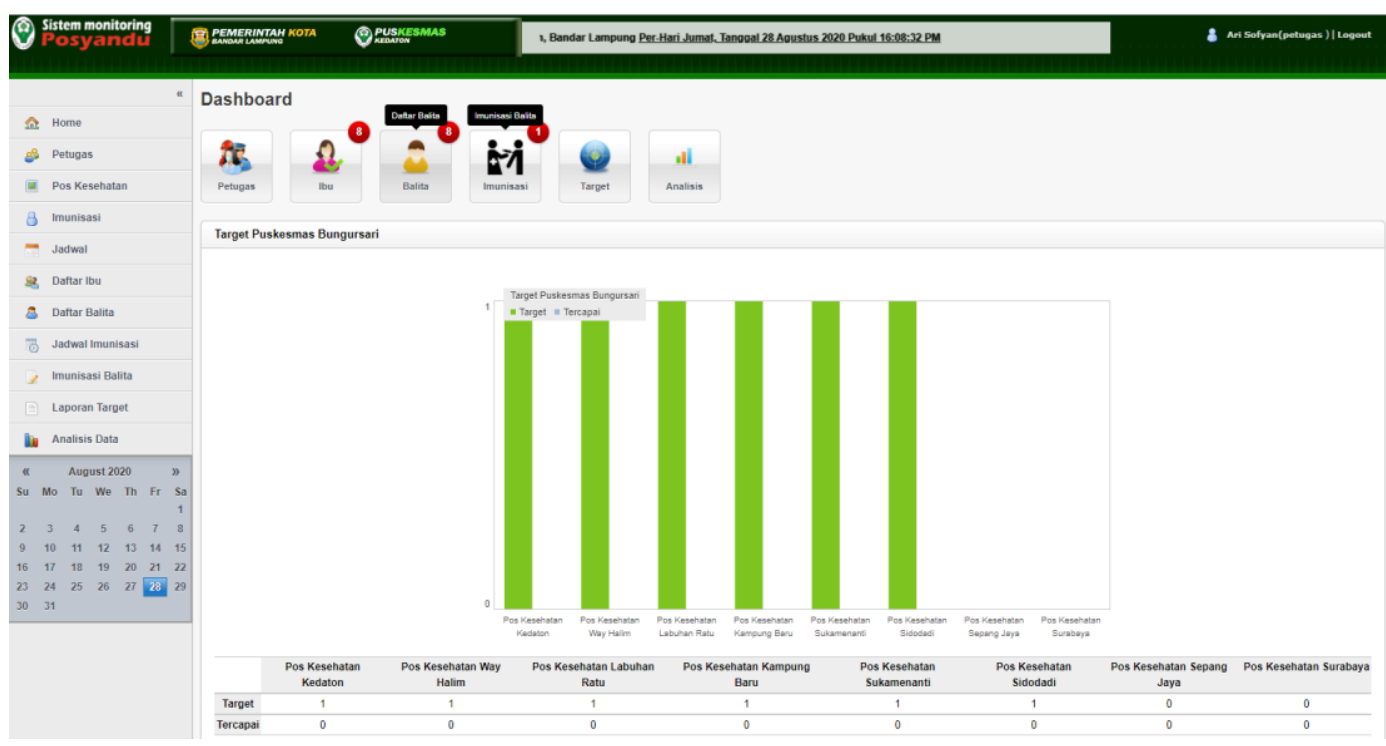

Gambar 7 Implementasi halaman utama Petugas

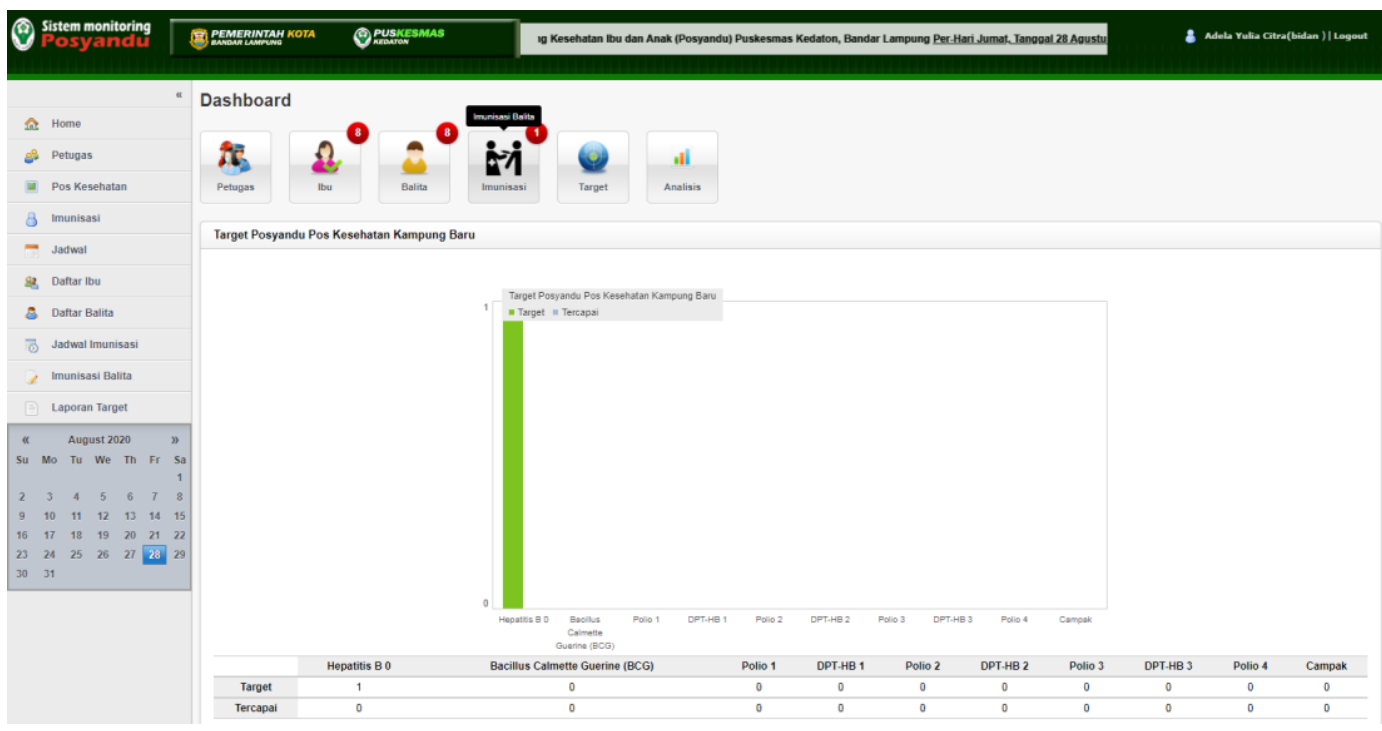

Gambar 8 Implementasi halaman utama Bidan

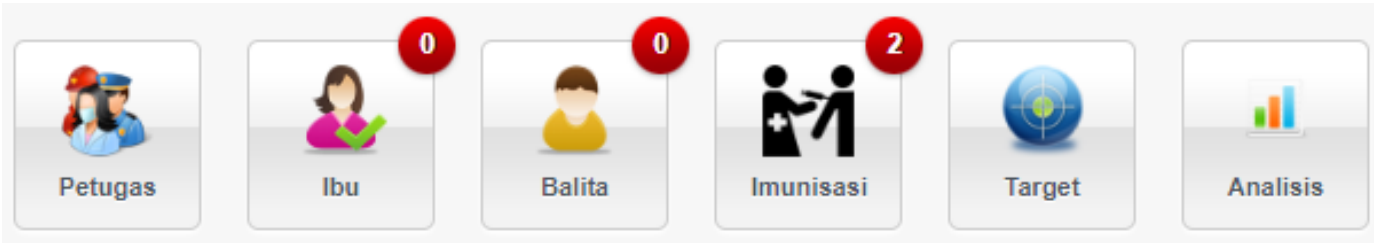

Gambar 9 Implementasi halaman konten dashboard

\subsubsection{Halaman pos monitoring}

Halaman menu lokasi atau pos sistem informasi monitoring tumbuh kembang balita digunakan menampilkan data informasi terkait dengan nama pos-pos untuk tempat monitoring. Halaman ini difungsikan untuk memberikan pelayanan kesehatan masyarakat di pos-pos atau daerah terpencil yang sulit dijangkau serta meningkatkan pelayanan kesehatan terutama berhubungan monitoring imunisasi dan pertumbuhan balita. Lokasi pos kesehatan di puskesmas kedaton Kota Bandar Lampung dipresentasikan ke pada Gambar 10. 


\begin{tabular}{|l|l|l}
\hline NO & \multicolumn{1}{|c|}{ NAMA } & \multicolumn{1}{c}{ TEMPAT } \\
\hline 1 & Pos Kesehatan Kedaton & Kelurahan Kedaton Kota Bandar Lampung 35141 \\
\hline 2 & Pos Kesehatan Way Halim & Perumnas Way Halim Kedaton Kota Bandar Lampung 35141 \\
\hline 3 & Pos Kesehatan Labuhan Ratu & Labuhan Ratu Kedaton Kota Bandar Lampung 35142 \\
\hline 4 & Pos Kesehatan Kampung Baru & Kampung Baru Kedaton Kota Bandar Lampung 35143 \\
\hline 5 & Pos Kesehatan Sukamenanti & Sukamenanti Kedaton Kota Bandar Lampung 35146 \\
\hline 6 & Pos Kesehatan Sidodadi & Sidodadi Kedaton Kota Bandar Lampung 35147 \\
\hline 7 & Pos Kesehatan Sepang Jaya & Sepang Jaya Kedaton Kota Bandar Lampung 35148 \\
\hline 8 & Pos Kesehatan Surabaya & Surabaya Kedaton Kota Bandar Lampung 35148 \\
\hline
\end{tabular}

Gambar 10 Implementasi halaman lokasi

\subsubsection{Halaman analisis data dengan metode Chi-Square (X2)}

Halaman menu target pelaporan merupakan halaman untuk menampilkan hasil pencapaian di masing-masing pos kesehatan yang telah terdata dan tertarget sesuai dengan waktu pelaporan sedangkan analisis data merupakan perhitungan dan grafik target dengan capaian pertumbuhan balita dengan menggunakan metode Chi-Square atau X2.

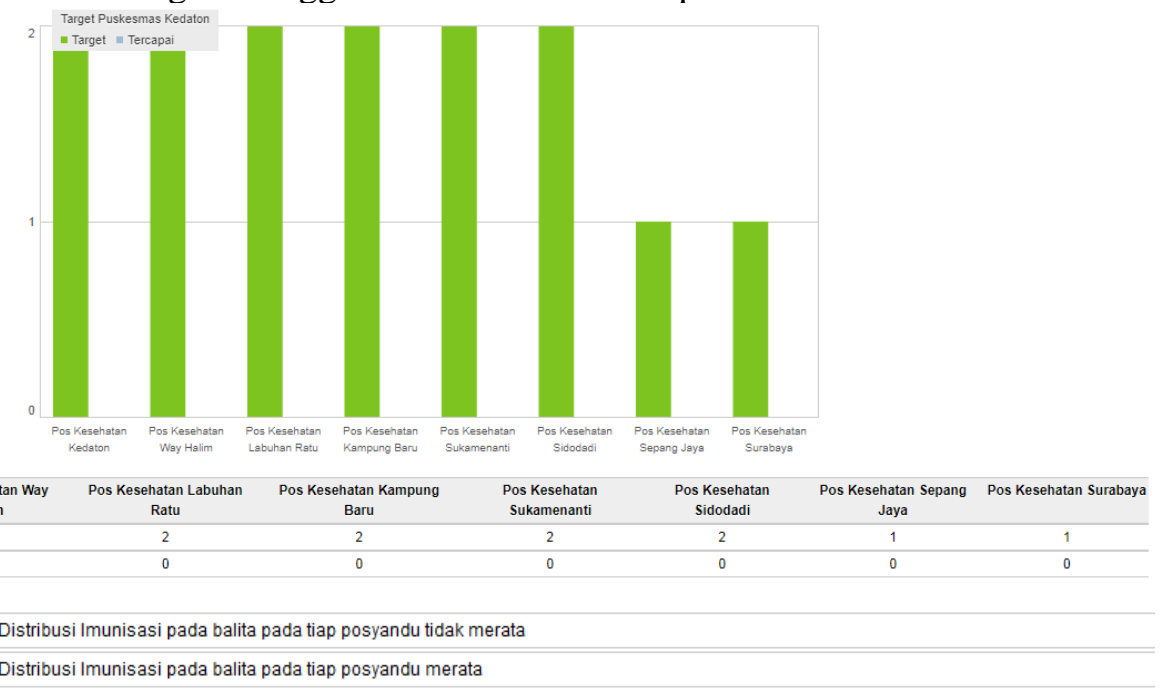

Gambar 11 Implementasi halaman analisis data

Dengan menggunakan formula dari metode Chi-Square (X2) maka perhitungan hasil sebagai berikut :

\begin{tabular}{|c|c|c|c|}
\hline \multicolumn{2}{|c|}{ RUMUS } & \multirow[t]{2}{*}{ PENGHITUNGAN } & HASIL \\
\hline \multicolumn{2}{|c|}{$\chi^{2}=\sum_{i=1}^{k} \frac{\left(o_{i}-e_{i}\right)^{2}}{e_{i}}$} & & 1.86 \\
\hline \multicolumn{4}{|c|}{ Oi : Frekuensi Observasi } \\
\hline \multicolumn{4}{|c|}{ Ei : Frekuensi Harapan } \\
\hline \multicolumn{4}{|c|}{$\mathrm{m}$ : Banyaknya kategori/kelas $(\mathrm{x}) \mathrm{a}$} \\
\hline \multicolumn{4}{|c|}{ a : Taraf (Standard 5\%) } \\
\hline \multicolumn{4}{|c|}{$\mathrm{v}$ : Derajad Kebebasan $(m-k-1)$} \\
\hline \multicolumn{4}{|c|}{ Nilai Kritis $(v=7, \alpha=0.05)=14.1$} \\
\hline Nilai Kritis & 14.1 & & \\
\hline Nilai Hitung & 1.86 & & \\
\hline Kesimpulan & Distribusi Imuni & a balita pada tiap posyandu tidak merata & \\
\hline
\end{tabular}


Berdasarkan dari monitoring nilai H0 (Hipotesis Nol) Distribusi Imunisasi pada balita pada tiap posyandu tidak merata dan H1 (Hipotesis Alternatif) Distribusi Imunisasi pada balita pada tiap posyandu merata. Sedangkan nilai kritis sebesar 14.1, nilai hitung sebesar 1.86 Sehingga hasil kesimpulan yang didapat bahwa proses distribusi penyebaran untuk imunisasi tumbuh kembang balita setiap titik-titik pos pelayanan terpadu tidak merata.

\subsection{Pengujian sistem}

Pengujian fokus pada proses di form yang terdapat pada aplikasi dan berikut ini adalah skenario pengujian pada perancangan sistem informasi tumbuh kembang balita berbasis web yang dipresentasikan pada Tabel 1.

Tabel 1 Skenario dan hasil pengujian

\begin{tabular}{|c|c|c|c|c|c|}
\hline No & $\begin{array}{c}\text { Antar muka } \\
\text { yang di uji }\end{array}$ & $\begin{array}{c}\text { Bagian } \\
\text { yang di uji }\end{array}$ & $\begin{array}{c}\text { Status } \\
\text { Aplikasi }\end{array}$ & $\begin{array}{l}\text { Skenario } \\
\text { Pengujian }\end{array}$ & $\begin{array}{c}\text { Hasil } \\
\text { Pengujian }\end{array}$ \\
\hline 1 & $\begin{array}{l}\text { Halaman } \\
\text { Login }\end{array}$ & $\begin{array}{l}\text { Menguji Menu } \\
\text { Login }\end{array}$ & $\begin{array}{l}\text { Tampilan } \\
\text { Login sudah } \\
\text { terbuka }\end{array}$ & $\begin{array}{l}\text { Input usernamel dan } \\
\text { password lalu klik } \\
\text { login }\end{array}$ & $\begin{array}{l}\text { Apabila benar } \\
\text { masuk ke } \\
\text { halaman home }\end{array}$ \\
\hline 2 & $\begin{array}{l}\text { Halaman } \\
\text { tambah petugas }\end{array}$ & $\begin{array}{l}\text { Menguji } \\
\text { Halaman form } \\
\text { tambah }\end{array}$ & $\begin{array}{l}\text { Masuk } \\
\text { halaman } \\
\text { menu petugas }\end{array}$ & $\begin{array}{l}\text { Pilih tambah lalu } \\
\text { klik isi form tambah } \\
\text { kemudian simpan }\end{array}$ & $\begin{array}{l}\text { Menampilkan } \\
\text { ke halaman } \\
\text { petugas }\end{array}$ \\
\hline 3 & $\begin{array}{l}\text { Halaman } \\
\text { tambah pos } \\
\text { kesehatan } \\
\text { balita }\end{array}$ & $\begin{array}{l}\text { Menguji } \\
\text { Halaman form } \\
\text { tambah }\end{array}$ & $\begin{array}{l}\text { Masuk } \\
\text { Halaman } \\
\text { menu } \\
\text { posyandu }\end{array}$ & $\begin{array}{l}\text { Pilih tambah lalu } \\
\text { klik isi form tambah } \\
\text { kemudian klik } \\
\text { simpan }\end{array}$ & $\begin{array}{l}\text { Dapat } \\
\text { menampilkan } \\
\text { data posyandu }\end{array}$ \\
\hline 4 & $\begin{array}{l}\text { Halaman menu } \\
\text { tambah } \\
\text { imunisasi }\end{array}$ & $\begin{array}{l}\text { Menguji } \\
\text { Halaman form } \\
\text { tambah }\end{array}$ & $\begin{array}{l}\text { Masuk } \\
\text { Halaman } \\
\text { menu } \\
\text { imunisasi }\end{array}$ & $\begin{array}{l}\text { Pilih tambah lalu } \\
\text { klik isi form tambah } \\
\text { kemudian klik } \\
\text { simpan }\end{array}$ & $\begin{array}{l}\text { Keluar dari } \\
\text { halaman } \\
\text { konten menu }\end{array}$ \\
\hline 5 & $\begin{array}{l}\text { Halaman menu } \\
\text { tambah jadwal }\end{array}$ & $\begin{array}{l}\text { Menguji } \\
\text { Halaman form } \\
\text { tambah jadwal }\end{array}$ & $\begin{array}{l}\text { Masuk ke hal. } \\
\text { menu tambah } \\
\text { jadwal }\end{array}$ & $\begin{array}{l}\text { Pilih menu } \\
\text { "tambah" lalu } \\
\text { lakukan klik }\end{array}$ & $\begin{array}{l}\text { Berhasil } \\
\text { menampilkan } \\
\text { data jadwal }\end{array}$ \\
\hline 6 & $\begin{array}{l}\text { Halaman menu } \\
\text { daftar ibu dan } \\
\text { balita }\end{array}$ & $\begin{array}{l}\text { Menguji } \\
\text { Halaman form } \\
\text { daftar }\end{array}$ & $\begin{array}{l}\text { Masuk } \\
\text { halaman } \\
\text { daftar }\end{array}$ & $\begin{array}{l}\text { Pilih menu } \\
\text { "tambah" lalu } \\
\text { lakukan klik }\end{array}$ & $\begin{array}{l}\text { Berhasil } \\
\text { menampilkan } \\
\text { data }\end{array}$ \\
\hline 7 & $\begin{array}{l}\text { Halaman menu } \\
\text { jadwal } \\
\text { imunisasi }\end{array}$ & $\begin{array}{l}\text { Menguji } \\
\text { Halaman form } \\
\text { jadwal }\end{array}$ & $\begin{array}{l}\text { Masuk ke } \\
\text { halaman menu } \\
\text { jadwal }\end{array}$ & $\begin{array}{l}\text { Pilih menu } \\
\text { "tambah" lalu } \\
\text { lakukan klik }\end{array}$ & $\begin{array}{l}\text { Berhasil } \\
\text { menampilkan } \\
\text { data jadwal }\end{array}$ \\
\hline 8 & $\begin{array}{l}\text { Halaman menu } \\
\text { data analisis }\end{array}$ & $\begin{array}{l}\text { Menguji } \\
\text { pengaturan } \\
\text { waktu }\end{array}$ & $\begin{array}{l}\text { Masuk ke } \\
\text { halaman menu }\end{array}$ & $\begin{array}{l}\text { Pilih menu } \\
\text { "tambah" lalu } \\
\text { lakukan klik }\end{array}$ & $\begin{array}{l}\text { Berhasil } \\
\text { menampilkan } \\
\text { data }\end{array}$ \\
\hline 9 & $\begin{array}{l}\text { Halaman menu } \\
\text { logout }\end{array}$ & $\begin{array}{l}\text { Menguji Menu } \\
\text { Logout }\end{array}$ & $\begin{array}{l}\text { Masuk menu } \\
\text { logout }\end{array}$ & $\begin{array}{l}\text { Klik tombol } \\
\text { logout }\end{array}$ & $\begin{array}{l}\text { Berhasil } \\
\text { keluar }\end{array}$ \\
\hline
\end{tabular}

Setelah dilakukan secara menyeluruh dari item menu yang telah dilakukan telah sesuai dengan yang diharapkan, form-form dari perancangan sistem, menghasilkan keluaran yang sesuai. Secara garis besar dari hasil keseluruhan pengujian yang telah dilakukan oleh peneliti, maka hasil pengujian telah sesuai dengan hasil yang diharapkan dengan dipaparkan hasil sebagai berikut, pada halaman login dan logout, sistem dapat melakukan masuk ataupun keluar dari seluruh halaman pengguna sistem, halaman tambah, hapus, perubahan data petugas, halaman tambah tumbuh kembang balita, yang terdiri dari halaman halaman menu tambah imunisasi wajib, halaman menu tambah jadwal, halaman menu daftar ibu dan balita, halaman menu jadwal imunisasi. Selain itu, konsep algoritma feature selection Chi-Square (X2) telah diterapkan pada halaman analisis data. 


\section{KESIMPULAN}

Setelah dilakukan serangkaian analisis dan hasil pengujian sistem informasi monitoring tumbuh kembang balita maka dapat di simpulkan bahwa sistem ini mampu memberikan sebuah model sistem monitoring berbasis antarmuka web yang dapat diakses dimana saja dan kapan saja, mampu memberikan sebuah model sistem yang dapat memonitoring secara langsung kondisi pertumbuhan kesehatan balita dan mampu memberikan sebuah model sistem yang dapat dimanfaatkan oleh petugas kesehatan baik petugas medis maupun bidan untu memonitoring titik-titik pos kesehatan desa. Selain itu, hasil perhitungan menggunakan algoritma Chi-Square (X2) sebesar 14.1 untuk nilai kritis dan 1.86 untuk nilai hitung sehingga distribusi penyebaran untuk imunisasi tumbuh kembang balita setiap titik-titik pos pelayanan terpadu tidak merata.

\section{DAFTAR PUSTAKA}

[1] Kementerian Kesehatan Republik Indonesia, 2016, Pedoman umum program Indonesia sehat dengan pendekatan keluarga, [pdf], (http://www. depkes.go.id/resources/download/ lain/Buku\%20Program\%20Indonesia\%20Sehat\%20dengan\%20Pendekatan\%20Keluarga. pdf, diakses tanggal 10 Agustus 2018)

[2] Pemerintah Provinsi Lampung, 2017, Pemprov Lampung Alokasikan Anggaran Bidang Kesehatan Di Atas Rata-Rata Nasional, [online], (http://lampungprov.go.id/berita/ pemprov-lampung-alokasikan-anggara-bidang-kesehatan-di-atas-rata-rata-nasional.html, diakses tanggal 13 Agustus 2018)

[3] Dinas Kesehatan Provinsi Lampung, 2016, Rencana Strategis Dinas Kesehatan Provinsi Lampung Tahun 2015 - 2019, [pdf], (https://dinkes.lampungprov. go.id/wp-content/ uploads/2016/07/1.renstra-dinas-kesehatan-provinsi-lampung-2015-2016.pdf, diakses tanggal 15 Agustus 2018)

[4] Dinas Kesehatan Kota Bandar Lampung, 2014, Profil Kesehatan Kota Bandar Lampung Tahun 2014, [pdf], (http://www.depkes.go.id/resources/ download/profil/profil_ kab_kota_2014/1871_Lampung_Kota_Bandar_Lampung_2014.pdf, diakses tanggal 15 Agustus 2018)

[5] Dennis, A. , Wixom, b. H. , \& Roth, R. M. (2012). System Analysis And Design. New Jersey: John Wiley \& Sons, Inc.

[6] Daniel Piter Kristian dan Nina Setiyawati. (2017). Perancangan Sistem Informasi Posyandu Berbasis Web menggunakan Framework CodeIgniter Studi Kasus: Posyandu "Kasih Ibu” Margosari). Universitas Kristen Satya Wacana Salatiga.

[7] Hilary Takudzwa Mushonga, Faustin Banda \& Augustine Mulolwa. (2017). Development of a web based GIS for health facilities mapping, monitoring and reporting: A case study of the Zambian Ministry of health, South African Journal of Geomatics, Vol. 6. No. 3, University of Zambia.

[8] Erin Song \& Puja Maheshwari. (2016). Using the Mobile Application ClickHealth to Provide Accessible Healthcare to the Homeless. Santa Clara, California.

[9] Nadia Savitri\&Heru Nurwasito. (2018). Pengembangan Aplikasi Mobile untuk Pelayanan Administrasi Posyandu dengan menggunakan Google Maps Api Geolocation Tagging. Jurnal Pengembangan Teknologi Informasi dan Ilmu Komputer Vol. 2, No. 1.

[10] I. Listiowarni and E. Rahayu Setyaningsih, "Analisis Kinerja Smoothing pada Naive Bayes untuk Pengkategorian Soal Ujian," J. Teknol. dan Manaj. Inform., vol. 4, no. 2, pp. $1-6,2018$.

[11] M. Alazab, "Automated malware detection in mobile app stores based on robust feature generation," Electron., vol. 9, no. 3, 2020. 
[12] A. H. Mohammad, "Applytwo Feature Selections ( Chi-Square and Symmetric Uncertainty ) Using C4 . 5 Classification Algorithm Based on Arabic Data Set," vol. 2, no. September, pp. 5-8, 2018.

[13] L. Ma et al., "Evaluation of feature selection methods for object-based land cover mapping of unmanned aerial vehicle imagery using random forest and support vector machine classifiers," ISPRS Int. J. Geo-Information, vol. 6, no. 2, 2017.

[14] M. Masih and A. Grant, "Chi square feature extraction based SVMS arabic language text categorization system," Talent Dev. Excell., vol. 9, no. 2, pp. 18-26, 2017.

[15] H. Zhang et al., "Informative gene selection and direct classification of tumor based on chi-square test of pairwise gene interactions," Biomed Res. Int., vol. 2014, no. ii, 2014.

[16] V. Barot, S. Singh Chauhan, and B. Patel, "Feature Selection for Modeling Intrusion Detection,” Int. J. Comput. Netw. Inf. Secur., vol. 6, no. 7, pp. 56-62, 2014.

[17] Dharmendra Kumar singh, Pragya Patel, Anjali Karsh, Dr.A.S.Zadgaonkar, Analysis of Generated Harmonics Due To CFL Load On Power System Using Artificial Neural Network, International Journal of Electrical Engineering and Technology (IJEET) Volume 5, Issue 3, pp. 56-68, 2014

[18] O. S. Bachri, Kusnadi, M. Hatta, and O. D. Nurhayati, "Feature selection based on CHI square in artificial neural network to predict the accuracy of student study period," Int. J. Civ. Eng. Technol., vol. 8, no. 8, pp. 731-739, 2017. 